\title{
Interference by Palisade Grass on Coffee Seedlings INOCUlated WITH ARBUSCULAR MYCORRHIZAL FUNGI ${ }^{1}$
}

\author{
Interferência de Braquiária em Mudas de Cafeeiro Inoculadas com Fungos Micorrizicos \\ Arbusculares
}

\author{
ALECRIM, A.O. ${ }^{2}$, FRANÇA, A.C. ${ }^{3}$, SANTOS, E.A. ${ }^{3}$, MOREIRA, S.D. ${ }^{3}$, LEAL, F.D.S. ${ }^{3}$, and \\ TIBÃES, E.S.R. ${ }^{3}$
}

\begin{abstract}
The purpose of this paper was to evaluate the effects of the interference by Urochloa brizantha on coffee seedlings inoculated with arbuscular mycorrhizal fungi. A randomized block design and a $4 \times 2$ layout was used, where factor A was constituted by seedlings inoculated with Rhizophagus clarus, Claroideoglomus etunicatum and Dentiscutata heterogama, as well as some that were not inoculated, and factor B, constituted by plants in competition or alone. The sowing was conducted on washed sand to produce the coffee seedlings, which, during the matchstick stage, were transplanted into polyethylene bags, and inoculated when showing six pairs of leafs. Then, they were transplanted into pots where they were subjected to interference from two plants of $U$. brizantha for 90 days, during which time their growth and nutrient accumulation were evaluated on the leaves. As a result, an interaction between the following factors was observed: plant height, leaf area, shoot dry weight, dry weight for roots and $\mathrm{P}, \mathrm{Mg}$ and $\mathrm{Zn}$ content in coffee seedlings. The damaging effect on the growth and P accumulation caused by the weed was reduced in coffee seedlings inoculated with mycorrhiza. Another conclusion was that the inoculation factor increases the competitive power of coffee seedlings.
\end{abstract}

Keywords: Coffea arabica, Rhizophagus clarus, Claroideoglomus etunicatum, Dentiscutata heterogama, Urochloa brizantha.

\begin{abstract}
RESUMO - Objetivou-se com este trabalho avaliar os efeitos da interferência de Urochloa brizantha (braquiária) em plantas de cafeeiro (Coffea arabica) inoculadas com fungos micorrizicos. Utilizou-se delineamento em blocos casualizados e disposição em esquema fatorial $4 \times 2$, em que o fator $A$ foi composto por mudas inoculadas com Rhizophagus clarus, Claroideoglomus etunicatum $e$ Dentiscutata heterogama e não inoculadas, e o fator $B$, por mudas de café sem e com interferência de U. brizantha. Fez-se a semeadura em areia lavada para produzir as mudas de café, que, quando atingiram a fase de "palito de fósforo", foram transplantadas para sacos de polietileno e inoculadas com os esporos dos fungos no estádio de seis pares de folhas. Em seguida, elas foram transplantadas para vasos, onde foram submetidas à interferência de duas plantas de $\boldsymbol{U}$. brizantha por 90 dias, quando foram avaliadas características de crescimento e acúmulo de nutrientes nas folhas. Como resultado, foram observadas interações entre os fatores altura de plantas, área foliar, massa seca da parte aérea, massa seca de raizes e teores de $P, \mathrm{Mg}$ e Zn em mudas de café. A competição com braquiária reduziu o crescimento e o acúmulo de matéria seca e fósforo das mudas de café, porém esses efeitos foram menores nas mudas inoculadas com os fungos micorrizicos arbusculares. Portanto, a inoculação aumenta o poder competitivo das mudas de café.
\end{abstract}

Palavras-chave: Coffea arabica, Rhizophagus clarus, Claroideoglomus etunicatum, Dentiscutata heterogama, Urochloa brizantha.

Recebido para publicação em 16.12.2015 e aprovado em 7.2.2016.

2 Universidade Federal de Lavras. Lavras-MG, Brasil, < ademilsonfederal@hotmail.com>; ${ }^{3}$ Universidade Federal dos Vales do Jequitinhonha e Mucuri. Diamantina-MG, Brasil. 


\section{INTRODUCTION}

The culture of coffee seedlings in important for the Brazilian economy, since it is classified as an agricultural commodity and it generates millions of Jobs along its productive chain, as well as income for the country. In addition, Brazil is the largest producer and exporter, with approximately 2.28 million planted hectares for this culture and estimated production of 44.6 million sacks in 2015 (CONAB, 2015).

Brazilian crops still show low productivity in relation to the production potential, and, among the main causes, are the culture of depauperate plants, the biannual production, oscillation on international prices, nutritional deficiencies and problems related to the phytosanitary management, mainly in relation to the interference of weeds (Oerke et al., 2005).

Weeds have a high capacity to compete for the resources available on the environment; therefore, failures on their management negatively affect the coffee production. The interference on coffee plants is significant, since several roots of the culture, which absorb nutrients more effectively, grow on the soil surface, where most of the roots of weeds are. On crops in formation, the competition is even higher, due to the large soil free area and a resulting higher availability of resources and conditions to invading plants. In addition, coffee seedlings are more sensitive to the interference due to the age and acclimatization period (Ronchi and Silva, 2006).

The interference from plants of the Urochloa genus on coffee seedlings negatively affects the dry matter accumulation, the physiological variables and the contents of the following nutrients $\mathrm{N}, \mathrm{P}, \mathrm{K}, \mathrm{Ca}, \mathrm{Mg}$ and S (Fialho et al., 2011, 2012; Matos et al., 2013). In order to avoid these damages, on recently implanted coffee plantations, several control methods are recommended, such as preventive management, the use of herbicides, mechanical control, etc., due to the crop characteristics.

The cultural control stands out, consisting in integrating ecological characteristics of the agrosystem, favoring the quick and sustainable establishment of the culture; this practice is widely promoted and adopted on coffee cultures all over the world. Therefore, the higher the number of beneficial practices to the plants, the higher will be their competitive capacity (Harker and O'donovan, 2013). In that sense, there is the fact that coffee seedlings associate to arbuscular mycorrhizal fungi (AMF), which confer several benefits to the culture: optimized use of resources and conditions, more efficient radicular system and higher tolerance to pathogens (Smith et al., 2010; França et al., 2014).

Arbuscular mycorrhizas are symbiotic associations between fungi and the roots of approximately $95 \%$ of vascular plants, including the ones on the culture, which confers several advantages to the plants, mainly a higher accumulation of slightly soluble nutrients (Smith et al., 2010). It is also noteworthy that, among the several AMF species, Rhizophagus, Claroideoglomus and Dentiscutata specimens stand out on inoculation programs on substrates, aiming at the production of more vigorous seedlings (França et al., 2014; Riter Netto et al., 2014; Augé et al., 2015). However, it has not yet been completely clarified whether AMFs confer to the coffee seedlings a higher competitive capacity in relation to the Urochloa brizantha (brachiaria) interference. For that reason, the objective of this paper was to evaluate the effects of the $U$. brizantha cv. Marandu interference on coffee seedlings inoculated with AMF.

\section{MATERIAL AND METHODS}

The experiment was conducted between the months of April 2013 and February 2014, on a greenhouse. Coffee seeds were used (Coffea arabica) from the Catuaí Vermelho IAC 99 cultivar, as well as three arbuscular mycorrhizal fungi (AMF) inoculations, which were constituted by sand, expanded clay, root fragments and Rhizophagus clarus, Claroideoglomus etunicatum and Dentiscutata heterogama spores, obtained from the International Culture Collection of Glomeromycota - CICG (www.furb.br/cicg).

For the production of inoculated seedlings, the coffee seeds were germinated on sand that had been previously washed with distilled 
water. When the seedlings reached the "matchstick" stage, they were transplanted into polyethylene bags with $1.6 \mathrm{dm}^{3}$ of soil, physically and chemically characterized (Table 1). No fertilizations were conducted on this soil. During the transplantation, 3/4 of the seedlings were inoculated with 100 spores each, placed through the addition of the abovementioned inoculum. The quantification of the density of the spores was conducted according to the wet screening technique on $50 \mathrm{~g}$ samples, followed by centrifugation on water and on sucrose, counting them afterwards with the help of a magnifying glass (Jenkins, 1964).

When they reached the stage of six definite pairs of leafs, the plants were transplanted into pots $(20.0 \mathrm{~L})$, filled with the same soil used to produce the seedlings, placing one coffee plant per pot. Tem days after the establishment of these plants, two Urochloa brizantha cv. Marandu seedlings, containing one fully expanded leaf, were transplanted at $10 \mathrm{~cm}$ from the coffee seedling, on opposite positions. The $U$. brizantha seedlings were obtained by germinating the seeds on washed sand with distilled water.

The treatments were arranged on randomized blocks and $4 \times 2$ factorial layout, in such a way that the coffee seedlings inoculated with $R$. clarus, $C$. etunicatum and D. heterogama and the ones that were not inoculated constituted factor A; and the presence or absence of $U$. brizantha represented factor B. In addition, four repetitions were used, and each pot constituted one experimental unit. The coexistence period for the plants comprehended 90 days.
On coffee plants, the following factors were evaluated: length and width of the leafs to determine the leaf area (Antunes et al., 2008), number of plagiotropic branches, number of leafs, diameter of the collected plants and dry mass of the roots. Then, all plants were cut close to the soil, divided into shoot and radicular system, placed on paper bags and put on a forced air circulation oven at $65^{\circ} \mathrm{C}$, in order to determine the dry mass. Leaf portions were grinded and subjected to nitro-perchloric digestion, in order to determine the $\mathrm{P}$ (Braga and De Fellipo, 1974), K (Jackson, 1958) and $\mathrm{Ca}, \mathrm{Mg}, \mathrm{Mn}, \mathrm{Fe}, \mathrm{Cu}$ and $\mathrm{Zn}$ contents (AOAC, 1975).

In order to verify the indirect effect of the AMF inoculation, the $U$. brizantha plants were evaluated as to the dry matter accumulation on the shoot and on the roots and as to the nutrient contents on the shoot. Finally, in order to interpret the results, the analysis of variance and the unfolding of the interaction were used, comparing means using Tukey's test at $5 \%$ of significance.

\section{RESULTS AND DISCUSSION}

There was an interaction among the factors for plant height, leaf area, shoot dry mass, root dry mass and $\mathrm{P}, \mathrm{Mg}$ and $\mathrm{Zn}$ contents on coffee seedlings. On Urochloa brizantha plants, an interaction was observed among the factors for shoot dry mass, root dry mass and $\mathrm{K}, \mathrm{Ca}, \mathrm{Mn}, \mathrm{Fe}$ and $\mathrm{Cu}$ contents. In addition, the coffee seedlings inoculated with arbuscular mycorrhizal fungi (AMF) showed a mycorrhizal colonization that was $119 \%$ higher in relation to the non-inoculated plants (Table 2).

Table 1 - Characterization of the dystrophic Red-Yellow Latosol used for the culture of coffee seedlings

\begin{tabular}{|c|c|c|c|c|c|c|c|c|c|}
\hline $\mathrm{pH}$ & $\mathrm{P}$ & $\mathrm{K}$ & $\mathrm{Ca}^{2+}$ & $\mathrm{Mg}^{2^{+}}$ & $\mathrm{Al}^{3+}$ & $\mathrm{H}+\mathrm{Al}$ & $\mathrm{T}$ & $\mathrm{t}$ & $\mathrm{OM}$ \\
\hline$\left(\mathrm{H}_{2} \mathrm{O}\right)$ & \multicolumn{2}{|c|}{$\left(\mathrm{mg} \mathrm{dm}^{-3}\right)$} & \multicolumn{6}{|c|}{$\left(\mathrm{cmol}_{\mathrm{c}} \mathrm{dm}^{-3}\right)$} & $\left(\right.$ dag kg $\left.^{-1}\right)$ \\
\hline 4.9 & 1.3 & 8 & 0.1 & 0.1 & 0.3 & 46 & 4.9 & 0.6 & 1.9 \\
\hline P-rem & $\mathrm{Zn}$ & $\mathrm{Fe}$ & $\mathrm{Mn}$ & $\mathrm{Cu}$ & B & Sand & \multicolumn{2}{|c|}{ Silt } & Clay \\
\hline$\left(\mathrm{mg} \mathrm{L}^{-1}\right)$ & \multicolumn{5}{|c|}{$\left(\mathrm{mg} \mathrm{dm}^{-3}\right)$} & \multicolumn{4}{|c|}{$(\%)$} \\
\hline 7.1 & 0.2 & 30.5 & 0.7 & 0.1 & 0.1 & 38 & & & 56 \\
\hline
\end{tabular}

$\mathrm{pH}$ water - soil-water relationship 1:2,5. $\mathrm{P}, \mathrm{K}, \mathrm{Cu}, \mathrm{Fe}, \mathrm{Mn}$ and $\mathrm{Zn}-$ Mehlich-1 extractor. $\mathrm{Ca}, \mathrm{Mg}$ and $\mathrm{Al}-\mathrm{KCl} 1$ mol L $\mathrm{L}^{-1}$ extractor. $\mathrm{H}+\mathrm{Al}$ - Calcium Acetate extract $0.5 \mathrm{~mol} \mathrm{~L}^{-1}$. OM - organic matter: carbon oxidation method by potassium dichromate on acid medium multiplied by 1.724 . - effective cation Exchange capacity. T - cation exchange capacity at $\mathrm{pH} 7.0$. 
Table 2 - Colonization by arbuscular mycorrhizal fungi on coffee seedlings after artificial inoculation and evaluation under the stage with six pairs of leafs

\begin{tabular}{|c|c|c|c|}
\hline No inoculation & Dentiscutata heterogama & Claroideoglomus etunicatum & Rhizophagus clarus \\
\hline \multicolumn{3}{|c|}{$(\%)$} & $37.20 \mathrm{a}$ \\
\hline $16.23 \mathrm{~b}$ & $34.21 \mathrm{a}$ & 17.32 & $35.31 \mathrm{a}$ \\
\hline VC $(\%)$ & & & \\
\hline
\end{tabular}

Means followed by the same letter do not differ from each other according to Tukey's test $(p<0.05)$.

The inoculation with AMF did not affect the height of the coffee seedlings when cultivated without the interference of $U$. brizantha. However, when the seedlings grew under the interference of the weed, the inoculation offered higher values regarding the height of the plants. In addition, the interference of $U$. brizantha reduced the height of the inoculated coffee seedlings (Table 3).

When evaluated in relation to the root dry mas, no difference was observed among the AMF species, and the mass means were $48.42 \mathrm{~g}$ and $35.25 \mathrm{~g}$ for plants without and with the interference of $U$. brizantha, respectively (Table 3). However, in that case, the inoculation was beneficial to the coffee plants, including when they were not subjected to the interference of the weed, since it offered a higher accumulation of roots. Additionally, AMFs offered a mean increase of $17.36 \%$ on the root dry mass, when there was no interference from $U$. brizantha, and of $24.55 \%$, when the weed was present (Table 3).

Usually, plants under this interference, especially under competition, use different tricks to reduce the damages of such relationship. Therefore, once they are competing for light, one strategy that is oftentimes used is the differentiated distribution of photoassimilates and cell elongation, with the intention of favoring the height gain to access light. Similarly, the roots may be favored to access resources from the soil, however, there is the need for primary acquisition of resources from the environment to produce carbohydrates and for the resulting growth (Gundel et al., 2014).

In that sense, the coffee plants, under this interference, show higher values for height and root dry mass, possibly due to the contribution obtained through the association to AMFs. Additionally, the pants cultivated without this interference showed no height increment, which shows the stem elongation factor in the search for light when the plants are fighting for resources.

Coffee seedlings that grew on a substrate inoculated with Rhizophagus clarus showed $85.55 \mathrm{~g}$ of shoot dry mass - a value that was $35 \%$ higher than the one related to noninoculated plants. However, on a substrate containing Claroideoglomus etunicatum and Dentiscutata heterogama, these dry mass values were similar to the ones where no inoculation occurred (Table 3). It is noteworthy that, although there is no difference on the biomass accumulation, the behavior of the seedlings occurred after the inoculation with $R$. clarus may be a result from the higher adaptation power of this fungus. Once it is better adapted to the rhizosphere conditions, it possibly promotes higher benefits to the host plant (Mohammadi, 2011).

Where there was $U$. brizantha interference, the shoot dry mass accumulation of the plants was not influenced by the inoculations. The seedlings accumulated, on average, $64.65 \mathrm{~g}$, a value that is $19 \%$ lower in relation to the mass accumulation where there was no interference from the weed. On the other hand, when inoculated with spores from $R$. clarus and $C$. etunicatum, the coffee plants produced a greater leaf area, in the presence or absence of competition with the weed (Table 3).

Also in relation to the leaf area of coffee seedlings, it was observed that the inoculation with $R$. clarus and $C$. etunicatum attenuated the damaging effect of the $U$. brizantha interference on this component, since the reduction of this parameter on plants that were not inoculated corresponded to $13.62 \%$, while this value was equivalent to $12.66 \%$ on plants containing the inoculated AMFs. Finally, as in all growth 
Table 3 - Growth variables of coffee plants (Catuaí Vermelho IAC 99) due to the inoculation by arbuscular mycorrhizal fungi and coexistence with Urochloa brizantha cv. Marandu for 90 days

\begin{tabular}{|c|c|c|c|c|}
\hline \multirow{3}{*}{ Fungi } & \multicolumn{4}{|c|}{ Urochloa brizantha } \\
\hline & No & Yes & No & Yes \\
\hline & \multicolumn{2}{|c|}{ Plant height $(\mathrm{cm})$} & \multicolumn{2}{|c|}{ Shoot dry mass $(\mathrm{g})$} \\
\hline No inoculation & $44.7 \mathrm{aA}$ & $31.7 \mathrm{bB}$ & $65.7 \mathrm{bA}$ & $56.9 \mathrm{aB}$ \\
\hline Dentiscutata heterogama & $44.8 \mathrm{aA}$ & $35.7 \mathrm{aB}$ & $81.7 \mathrm{abA}$ & $62.0 \mathrm{aB}$ \\
\hline Claroideoglomus etunicatum & $45.9 \mathrm{aA}$ & $38.5 \mathrm{aB}$ & $83.2 \mathrm{abA}$ & $68.8 \mathrm{aB}$ \\
\hline Rhizophagus clarus & $46.9 \mathrm{aA}$ & $38.7 \mathrm{aB}$ & $88.5 \mathrm{aA}$ & $70.8 \mathrm{aB}$ \\
\hline $\mathrm{VC}(\%)$ & \multicolumn{2}{|c|}{4.39} & \multicolumn{2}{|c|}{17.70} \\
\hline Fungi & \multicolumn{2}{|c|}{ Root dry mass (g) } & \multicolumn{2}{|c|}{ Leaf area $\left(\mathrm{cm}^{2}\right)$} \\
\hline No inoculation & $41.2 \mathrm{bA}$ & $27.5 \mathrm{bB}$ & $1815.2 \mathrm{bA}$ & $1568.0 \mathrm{bB}$ \\
\hline Dentiscutata heterogama & $47.5 \mathrm{aA}$ & $34.5 \mathrm{aB}$ & $1951.8 \mathrm{abA}$ & $1693.1 \mathrm{abB}$ \\
\hline Claroideoglomus etunicatum & $49.0 \mathrm{aA}$ & $34.2 \mathrm{aB}$ & $2062.7 \mathrm{aA}$ & $1808.5 \mathrm{aB}$ \\
\hline Rhizophagus clarus & $48.7 \mathrm{aA}$ & $34.0 \mathrm{aB}$ & $2089.2 \mathrm{aA}$ & $1824.8 \mathrm{aB}$ \\
\hline $\mathrm{VC}(\%)$ & \multicolumn{2}{|c|}{13.87} & \multicolumn{2}{|c|}{6.12} \\
\hline
\end{tabular}

For each variable, means followed by the same lowercase letter, on the column, do not differ from each other according to Tukey's test $(p<0.05)$, and those followed by the same uppercase letter on the row do not differ from each other according to the $\mathrm{F}$ test $(p<0.05)$.

variables, the $U$. brizantha interference on the coffee plant caused a reduction on the leaf area of the seedlings (Table 3).

The coffee seedlings from the Catuaí Vermelho IAC 99 variety used on this paper showed, as a competitive attribute influenced by AMFs, in relation to the weed, a height increase (for all fungi) and a leaf area increase (for the inoculation with $C$. etunicatum and $R$. clarus). In that sense, it is pointed out that coffee seedlings (Catuai Amarelo) had the leaf area as the most sensitive parameter to the competition with the weed (Dias et al., 2004). In addition, plants from the Urochloa genus showed an aggressive radicular growth, which confers them greater sustainability in relation to abiotic or biotic stress (including the interference from coffee seedlings). This fact would suppress the higher growth capacity of the coffee seedlings, in they do not have a constant access to water and nutrients resources obtained through the symbiosis with AMFs.

After evaluating whether the $U$. brizantha plants had been affected by the competition with the coffee seedlings inoculated with AMFs, it was observed that, for the root dry mass values, the mean accumulation of the plants under the interference of the coffee seedling inoculated with AMFs was $72.92 \mathrm{~g}$, a value that is $12.93 \%$ lower than the one obtained with roots in which there was not inoculation with fungi (Table 4).

When evaluating the shoot dry mass of $U$. brizantha plants, it was observed that where the inoculation with $C$. etunicatum spores occurred, there was a lower biomass accumulation, in relation to the coffee plants without inoculation or inoculated with $D$. heterogama. In addition, coffee plants inoculated with $R$. clarus caused a reduction of $12.3 \%$ on the root dry mass of $U$. brizantha (Table 4).

The photoassimilates distribution on $U$. brizantha plants depends heavily on

Table 4 - Dry mass (g) of two Urochloa brizantha cv. Marandu plants after coexisting for 90 days on a soil containing one coffee seedlings (Catuaí Vermelho IAC 99) inoculated with mycorrhizas

\begin{tabular}{|l|c|l|}
\hline \multicolumn{1}{|c|}{ Fungi } & Roots & \multicolumn{1}{c|}{ Shoot } \\
\hline No inoculation & $83.75 \mathrm{a}$ & $30.10 \mathrm{a}$ \\
\hline Dentiscutata heterogama & $73.75 \mathrm{~b}$ & $28.90 \mathrm{ab}$ \\
\hline Claroideoglomus etunicatum & $72.25 \mathrm{~b}$ & $25.25 \mathrm{c}$ \\
\hline Rhizophagus clarus & $72.75 \mathrm{~b}$ & $26.40 \mathrm{bc}$ \\
\hline VC $(\%)$ & 6.12 & 11.08 \\
\hline
\end{tabular}

Means followed by the same letter, on the column, do not differ from each other according to Tukey's test $(p<0.05)$.

Planta Daninha, Viçosa-MG, v. 34, n. 4, p. 681-689, 2016 
the environmental conditions. On noninterference, or non-shading, situations, the plant invests on leafs and increases its leaf area index; simultaneously, this greater leaf area confers a greater accumulation of photoassimilates and a resulting higher growth of the roots. On the other hand, when it perceives shading, the plant invests on elongating the cells of the culm, aiming at gaining height and accessing light (Dias-Filho, 2002). In that sense, it was observed that AMFs offer greater height, leaf area and higher radicular growth on coffee plants, which generated a reduction on the biomass accumulation by the $U$. brizantha plants.

Regarding the accumulation of nutrients on the leafs of coffee plants, it was observed that the phosphorus contents on plants under the interference of $U$. brizantha were lower; however, this difference was influenced by the inoculated AMF species. A content equivalent to $0.187 \mathrm{dag} \mathrm{kg}^{-1}$ was observed on plants without interference and non-inoculated, and $0.156 \mathrm{dag} \mathrm{kg}^{-1}$ where there was interference, which represents a reduction of $16.58 \%$. When the plants were inoculated with $\mathrm{AMFs}$, this reduction was equivalent to $18.62 \%$, considering all AMFs, and to $13.25 \%$, considering only $R$. clarus (Table 5).

Without the interference of $U$. brizantha, leafs of coffee plants inoculated with $R$. clarus accumulated $0.234 \mathrm{dag} \mathrm{kg}^{-1}$ of phosphorus, a value that was $25.13 \%$ higher than the one obtained when there was no inoculation. However, when there was an interference from the weed, the accumulation of phosphorus was $30.13 \%$ higher, when the concentration was equivalent to $0.203 \mathrm{dag} \mathrm{kg}^{-1}$ (Table 5). These facts show the gain in phosphorus absorption by coffee seedlings inoculated with $R$. clarus when in competition with $U$. brizantha.

Among the mechanisms involved in the higher acquisition of phosphorus by mycorrhizal plants is the production of organic acids, which promote the solubilization of the inorganic phosphatic material or chelation of cations that follow the phosphate anion; in addition, due to the extension of the radicular system conferred by hyphae, there is a greater exploration of the soil and access to phosphorus (Mohammadi, 2011). These processes are extremely important for the coffee culture worldwide, However, due to the improvement of the culture, the different methods and culture regions, the gains are influenced by the AMF specimen (Beenhouwer et al., 2015).

On this paper, the higher phosphorus accumulation observed on coffee plants inoculated with $R$. clarus, when under the interference of $U$. brizantha, means an improvement on the competitive potential of the culture, since, in several coffee crops, specimens of the Urochloa genus are cultivated in between the rows (Serafim et al., 2011). Intercropping also occurs (Lyngbaek et al., 2001), where the coffee plants are affected and where the cultural control of weeds must be a priority. Moreover, the fertilization management, especially with phosphorus, is directly related to the sustainability of the activity.

In relation to the magnesium accumulation on coffee leafs, it was observed that the contents were not influenced by

Table 5 - Leaf contents of nutrients on coffee plants (Catuaí Vermelho IAC 99) due to the inoculation by arbuscular mycorrhizal fungi and coexistence with Urochloa brizantha cv. Marandu for 90 days

\begin{tabular}{|c|c|c|c|c|c|c|}
\hline \multirow{3}{*}{ Fungi } & \multicolumn{6}{|c|}{ Urochloa brizantha } \\
\hline & No & Yes & No & Yes & No & Yes \\
\hline & \multicolumn{2}{|c|}{$\mathrm{P}\left(\right.$ dag kg $\left.^{-1}\right)$} & \multicolumn{2}{|c|}{$\mathrm{Mg}\left(\right.$ dag kg $\left.^{-1}\right)$} & \multicolumn{2}{|c|}{$\mathrm{Zn}\left(\mathrm{mg} \mathrm{kg}^{-1}\right)$} \\
\hline No inoculation & $0.187 \mathrm{bA}$ & $0.156 \mathrm{bB}$ & $0.016 \mathrm{aA}$ & $0.020 \mathrm{aA}$ & $4.88 \mathrm{aA}$ & $4.04 \mathrm{aB}$ \\
\hline Dentiscutata heterogama & $0.225 \mathrm{abA}$ & $0.179 \mathrm{abB}$ & $0.011 \mathrm{aA}$ & $0.007 \mathrm{bA}$ & $5.31 \mathrm{aA}$ & $4.05 \mathrm{aB}$ \\
\hline Claroideoglomus etunicatum & $0.221 \mathrm{abA}$ & $0.172 \mathrm{abB}$ & $0.017 \mathrm{aA}$ & $0.017 \mathrm{aA}$ & $5.74 \mathrm{aA}$ & $4.02 \mathrm{aB}$ \\
\hline Rhizophagus clarus & $0.234 \mathrm{aA}$ & $0.203 \mathrm{aB}$ & $0.020 \mathrm{aA}$ & $0.017 \mathrm{aA}$ & $5.79 \mathrm{aA}$ & $4.79 \mathrm{aB}$ \\
\hline $\mathrm{VC}(\%)$ & \multicolumn{2}{|c|}{10.88} & \multicolumn{2}{|c|}{31.81} & \multicolumn{2}{|c|}{13.14} \\
\hline
\end{tabular}

For each nutrient, means followed by the same lowercase letter, on the column, do not differ from each other according to Tukey's test $(p<0.05)$, and those followed by the same uppercase letter on the row do not differ from each other according to the $\mathrm{F}$ test $(p<0.05)$. 
the inoculation factor when there was no interference from $U$. brizantha. On these treatments, the plants accumulated approximately $0.016 \mathrm{dag} \mathrm{kg}^{-1}$. In addition, within each inoculation factor, there was no effect of the presence of $U$. brizantha. On the other hand, when coffee plants grew together with weeds, a lower accumulation of the nutrient was observed when the plants were inoculated with $D$. heterogama (Table 5).

Since they promote a buffer action on the soil, AMFs do not increase the availability of magnesium on the solution and, consequently, it's content on the plants. Another related factor would be the dilution effect on the element on the tissues (Giri and Mukerji, 2004; Andrade et al., 2009). Probably, due to these reasons, coffee plants inoculated with $D$. heterogama showed a lower magnesium accumulation in comparison to those that were not inoculated or treated with $C$. etunicatum and $R$. clarus, when under the interference of $U$. brizantha.

The $U$. brizantha plants caused a reduction on the zinc accumulation on coffee leafs, when a mean reduction of $22.19 \%$ was quantified. However, the inoculation factor did not influence the metal contents, when it was observed that the mycorrhizal plants accumulated $4.95 \mathrm{mg} \mathrm{kg}^{-1}$, and the nonmycorrhizal ones accumulated $4.46 \mathrm{mg} \mathrm{kg}^{-1}$ (Table 5). As with phosphorus, zinc also has low solubility on the soil and, for this reason, its activity is largely influenced by the action of AMFs (Mohammadi, 2011); however, on this paper, the competition imposed by $U$. brizantha for the resource (zinc) damaged the coffee plants, as already reported by Fialho et al. (2012).
With the purpose of defining the critical ranges of elements for the nutrition of coffee seedlings (Coffea arabica), Gonçalves et al. (2009) highlight phosphorus values between 0.22 and 0.25 dag $\mathrm{kg}^{-1}$. For Gontijo et al. (2007), these values, for the zinc micronutrient, are between 3.68 and $4.08 \mathrm{mg} \mathrm{kg}^{-1}$. Therefore, considering the low fertility shown by the substrate used on the experiment (Table 1) and the lack of fertilization, it is observed a higher competitive power from coffee seedling for the phosphorus resource; on the other hand, even with the interference of brachiaria plants, the zinc accumulation was not influenced, possibly since it was already within the interval demanded by the plants.

In relation to the nutrient accumulation on the $U$. brizantha leafs, no effect from the inoculation was observed on coffee seedlings. The mean values quantified were 2.14 and $0.17 \mathrm{dag} \mathrm{kg}^{-1}$ for potassium and calcium, respectively, and 4.57, 77.95 and $66.14 \mathrm{mg} \mathrm{kg}^{-1}$ for copper, iron and manganese, respectively (Table 6), which may be explained by the low competitive power of inoculated coffee seedlings in relation to the plants from the Urochloa genus (Dias et al., 2004; Fialho et al., 2010, 2011).

On papers conducted by Santos et al. (2002) and Carneiro et al. (2011), the inoculation of $\mathrm{AMF}$ on fodder legume seedlings, on an intercropping system with $U$. brizantha, favored the production of biomass by the former, and the global gain of protein by the system, with no damages to Poaceae. Additionally, among several authors, Marin and Weiner (2014) and Andrade et al. (2016) point out that, among the main dominance characteristics of Urochloa plants on cultures is the quick growth and

Table 6 - Leaf contents of nutrients on Urochloa brizantha cv. Marandu plants after coexisting for 90 days on a soil containing coffee seedlings (Catuaí Vermelho IAC 99) inoculated with arbuscular mycorrhizal fungi

\begin{tabular}{|l|c|c|c|c|c|c|}
\hline \multirow{2}{*}{ Fungi } & $\mathrm{P}$ & $\mathrm{Ca}$ & $\mathrm{Cu}$ & $\mathrm{Fe}$ & $\mathrm{Mn}$ \\
\cline { 2 - 7 } & \multicolumn{2}{|c|}{$(\mathrm{dag} \mathrm{kg})$} & \multicolumn{3}{c|}{$\left(\mathrm{mg} \mathrm{kg}^{-1}\right)$} \\
\hline No inoculation & $1.77 \mathrm{a}$ & $0.173 \mathrm{a}$ & $4.38 \mathrm{a}$ & $76.97 \mathrm{a}$ & $65.94 \mathrm{a}$ \\
\hline Dentiscutata heterogama & $2.21 \mathrm{a}$ & $0.171 \mathrm{a}$ & $4.64 \mathrm{a}$ & $76.97 \mathrm{a}$ & $62.13 \mathrm{a}$ \\
\hline Claroideoglomus etunicatum & $2.28 \mathrm{a}$ & $0.172 \mathrm{a}$ & $4.71 \mathrm{a}$ & $76.96 \mathrm{a}$ & $67.47 \mathrm{a}$ \\
\hline Rhizophagus clarus & $2.30 \mathrm{a}$ & $0.167 \mathrm{a}$ & $4.53 \mathrm{a}$ & $80.91 \mathrm{a}$ & $69.00 \mathrm{a}$ \\
\hline VC (\%) & 17.93 & 16.30 & 8.98 & 9.10 & 12.13 \\
\hline
\end{tabular}

Means followed by the same letter, on the column, do not differ from each other according to Tukey's test $(p<0.05)$. 
accumulation of nutrients during the first stages of life; these factors are further evidence for the need to provide better conditions to the establishment of coffee seedlings on environments where plants from the Urochloa genus occur.

To conclude, it was observed that the coffee seedlings inoculated with arbuscular mycorrhizal fungi, and under the influence of Urochloa brizantha plants, showed higher growth and accumulation of phosphorus in comparison to those that were not inoculated with fungi. In addition, the inoculated seedlings promoted a reduction on the biomass of $U$. brizantha plants when in competition.

\section{ACKNOWLEDGEMENTS}

To CNPq, to CAPES and to FAPEMIG, for their financial support to conduct this paper.

\section{REFERENCES}

Andrade A.S. et al. Simulating tropical forage growth and biomass accumulation: an overview of model development and application. Grass Forage Sci. 2016;71:54-65.

Andrade A.S. et al. Arbuscular mycorrhizal association in coffee. J Agric Sci. 2009; 147:105-15.

Antunes W.C. et al. Allometric models for non-destructive leaf area estimation in coffee (Coffea arabica and Coffea canephora). Ann Appl Biol. 2008;153:33-40.

Association of Official Analytical Chemists - AOAC. Official methods of analysis. $12^{\text {th }}$.ed. Washigton: 1975 . $1094 p$.

Augé R.M. et al. Arbuscular mycorrhizal symbiosis alters stomatal conductance of host plants more under drought than under amply watered conditions: a meta-analysis.

Mycorrhiza. 2015;25:13-24.

Beenhouwer M. et al. DNA pyrosequencing evidence for large diversity differences between natural and managed coffee mycorrhizal fungal communities. Agron Sustain Develop. 2015;35:241-9.

Braga J.M., De Fellipo B.V. Determinação espectrofotométrica de fósforo em extratos de solos e plantas. Rev Ceres. 1974;21:73-85.

Carneiro R.F.V. et al. Inoculação micorrízica arbuscular e adubação fosfatada no cultivo de forrageiras consorciadas. Arch Zootec. 2011;60:1191-202.

Planta Daninha, Viçosa-MG, v. 34, n. 4, p. 681-689, 2016
Companhia Nacional de Abastecimento -

CONAB. Acompanhamento da safra brasileira. 2015.

[acesso em: 02 abr. 2015] Disponível em: http://

www.conab.gov.br.

Dias G.F.S. et al. Brachiaria decumbens supresses the initial growth of Coffea Arabica. Sci Agric. 2004;61:579-83.

Dias Filho M.C. Photosynthetic light response of the C4 grasses Brachiaria brizantha and B. humidicola under shade. Sci Agric. 2002;59:65-8.

Fialho C.M.T. et al. Interferência de plantas daninhas sobre o crescimento inicial de Coffea arabica. Planta Daninha. 2011;29:137-47.

Fialho C.M.T. et al. Teor foliar de nutrientes em plantas daninhas e de café cultivadas em competição. Planta Daninha. 2012;30:65-73.

França A.C. et al. Crescimento de mudas de cafeeiro inoculadas com fungos micorrízicos arbusculares. Rev Bras Cienc Agr. 2014;9:506-11.

Giri B., Mukerji K.G. Mycorrhizal inoculant alleviates salt stress in Sesbania aegyptiaca and Sesbania grandiflora under field conditions: evidence for reduced sodium and improved magnesium uptake. Mycorrhiza. 2004;14:307-12.

Gonçalves S.M. et al. Faixas críticas de teores foliares de macronutrientes em mudas de cafeeiro (Coffea arabica.) produzidas em tubetes. Cienc Agrotecnol. 2009;33:743-52.

Gontijo R.A.N. et al. Faixas críticas de teores foliares de micronutrientes em mudas de cafeeiro (Coffea Arabica L.). Coffee Sci. 2007:2:135-41.

Gundel P.E. et al. Competing neighbors: light perception and root function. Ecologia. 2014:176:1-10.

Harker K.N., O’donovan J.T. Recent weed control, weed management, and integrated weed management. Weed Technol. 2013:27:1-11.

Jackson M.L. Soil chemical analysis. New Jersey: Prentice Hall, 1958. 521p.

Jenkins W.R. A rapid centrifugal-flotation technique for separating nematodes from soil. Plant Dis. 1964:48:692

Lyngbaek A.E. et al. Productivity and profitability of multistrata organic versus conventional coffee farms in Costa Rica. Agrofor Syst. 2001:53:205-13.

Marín C., Weiner, J. Effects of density and sowing pattern on weed suppression and grain yield in three varieties of maize under high weed pressure. Weed Res. 2014;54:467-74.

Matos C.C. et al. Características fisiológicas do cafeeiro em competição com plantas daninhas. Biosci J. 2013;29:1111-9. 
Mohammadi K. A review: beneficial effects of the mycorrhizal fungi for plant growth. J Appl Environ Biol Sci. 2011;1:310-9.

Oerke E.C. Centenary review - Crop losses to pests. J Agric Sci. 2006:144:31-43.

Riter Netto A.F. et al. Efeito de fungos micorrízicos arbusculares na bioprodução de fenóis totais e no crescimento de Passiflora alata Curtis. Rev Bras Plantas Medic. 2014;16:1-9.

Ronchi C.P., Silva A.A. Effects of weed species competition on the growth of young coffee plants. Planta Daninha. 2006;24:415-23.
Santos I.P.A. et al. Influência do fósforo, micorriza e nitrogênio no conteúdo de minerais de Brachiaria brizantha e Arachis pintoi consorciados. Rev Bras Zootec. 2002;31:605-16.

Serafim M.E. et al. Sistema conservacionista e de manejo intensivo do solo no cultivo de cafeeiros na região do Alto São Francisco, MG: um estudo de caso. Biosci J. 2011;27:96477.

Smith S.E. et al. Plant performance in stressful environments: interpreting new and established knowledge of the roles of arbuscular mycorrhizas. Plant Soil. 2010;326:3-20. 